\title{
CLASSIFICATION FOR TAX PURPOSES OF RESERVES OF TAX-EXEMPT COOPERATIVES
}

\begin{abstract}
W.L. BRADLEY*
Section ror, paragraph I2, of the Internal Revenue Code grants to bona fide agricultural cooperatives which meet its requirements an exemption from corporation income, excess profits, and capital stock taxes. ${ }^{1}$ Basic regulations of the Treasury Department have been promulgated to implement these provisions of the statute.

It is not the purpose of this article to discuss the merits of this exemption, which has of late been the subject of much public discussion and controversy. We are here concerned with an analysis of those criticisms directed at abuses of the exemption which may have some foundation in fact. We shall consider proposals which, if adopted, may be reasonably certain to cure the defects, should they in fact exist. Fair-minded men among the proponents and supporters of this tax exemption for cooperatives will readily agree that if the present-day development of these organizations has produced business practices, not covered by existing regulations, which afford opportunities for abuse of the exemption privilege, or result in the elimination from ultimate taxation to someone of any substantial part of the margins realized by the cooperative, they should be recognized, and corrective measures adopted.

There are many who have studied this situation who believe that the basic problems with respect to the tax exemption of cooperatives stem from the inadequacy of the present Treasury Regulations on this subject. They are equally sure that these matters can be adequately covered and controlled by simple amendments to the Treasury Regulations, and that an amendment to the present Internal Revenue Code is not required to effect a remedy.

The basic criticisms of the exemption applied to agricultural cooperatives by the provisions of the Code and Regulations, as they now read, seem to center on the following:

I. That through the accumulation of substantial reserves, even though for necessary business purposes, a substantial amount of income which should be taxable to someone may escape taxation.

2. That substantial amounts, distributed by the cooperatives as patronage refunds, which would be taxable to the patron, may not in fact be returned by the patron and made subject to tax.

- Practicing Certified Public Accountant, New York. Chairman of the Standing Coinmittee on Cooperative Accounting of the American Institute of Accountants; chairman of the Committec on Education in Cooperative Accounting, Terminology and Taxation of the American Institute of Cooperation; member of the Legal and Tax Committee of the National Council of Farmer Cooperatives.

${ }^{1} 53$ STAT. 876 (1939), 26 U.S.C. \$ror(12) (1940).
\end{abstract}


The answer to these problems may be found simply by spelling out in the regulations relating to and interpreting the applicable provisions of the Internal Revenue Code definite measures pertaining to:

r. Classification of permitted reserves.

2. Definitive limits on permitted reserves.

3.-Definitive rules with respect to the taxability of amounts, retained in reserves of the cooperatives, as income of the patrons.

4. Provisions for reporting information at the source with respect to patronage refunds paid or credited by an exempt agricultural cooperative.

Section ror(12) of the Internal Revenue Code provides that the exemption of an agricultural cooperative association otherwise qualified shall not be denied "because there is accumulated and maintained by it a reserve required by State law or a reasonable reserve for any necessary purpose." The corresponding provision of Regulations III (Section 29.IOI(I2)-I(a)) reads as follows:

The accumulation and maintenance of a reserve required by State statute, or the accumulation and maintenance of a reasonable reserve or surplus for any necessary purpose, such as to provide for the erection of buildings and facilities required in business or for the purchase and installment of machinery and equipment or to retire indebtedness incurred for such purposes, will not destroy the exemption. ${ }^{2}$

While this Regulation in its present form attempts to define and limit the purposes for which reserves can be created and the amounts which can be accumulated in such reserves, subject to the discretionary judgment of the Commissioner with respect to necessity and amount, both the statute and the Regulations are silent on the very important matter of how and when the amounts so retained shall be taxable to the patron to whom such equities belong. This omission from the Regulations might permit the accumulation of-substantial sums which, while meeting the requirements both of necessity and reasonableness for a reserve, might never be subject to taxation in the hands of either the cooperative or the patron. This constitutes the basic problem. The answer lies in the fact that it is not inconsistent with the statute for the Regulations to provide that while amounts may be accumulated by an exempt cooperative in a reserve without prejudice to its rights to exemption, the equities of patrons so retained and utilized can and should be subject to definite rules with respect to the time and manner of their taxation as income to the patron to whom they belong.

The problem would be simplified if the regulations prescribed a classification of, and perhaps some limitation with respect to, reserves which an exempt cooperative would be permitted to accumulate. The following suggestions are submitted.

x. Valuation reserves. The reserves for depreciation, depletion, and bad debts, and those affecting valuation of other balance sheet items to be accrued by an exempt agricultural cooperative, are in the same category as like reserves accumulated and maintained by any tax-paying corporation. It therefore seems proper that with

'U. S. Treas. Reg. III, 529.10(I2)-I (2) (I943). 
respect to the accumulation of these reserves the rules set forth in the applicable paragraphs of Section 23 of the Internal Revenue Code and the corresponding Regulations $^{3}$ should apply. Section 29.IOr-I2 of the Regulations provides that an agricultural cooperative shall do business with its patrons at cost. Any departure from the general rules with respect to the accrual of valuation reserves applicable to any tax-paying corporation might permit the distortion of annual costs by the inclusion of excessive provisions for these reserves. In as much as these valuation reserves are calculated to measure loss in value from use, they do not, if properly accrued, represent an accumulation of equity which would require the earmarking of each patron's share therein. They merely reflect a compensatory return of capital and do not represent any equity belonging, and taxable, to the patron as such.

2. Contingent reserves. The cooperative statutes of several states require that agricultural cooperatives maintain a reserve for contingencies for the protection of the capital and financial integrity of the association and to permit it to absorb shocks and losses which may occur in the operation of any business enterprise. Congress and the several legislatures have recognized that this procedure conforms to considerations of prudence. It would seem that even where the cooperative statutes of a state do not require the maintenance of such a reserve, the establishment and accrual of a reserve for that purpose comes clearly within the purview of a reserve for a necessary business purpose. The accumulation of a reasonable reserve for contingencies, therefore, should be permitted without prejudice to the tax-exempt status of the association, whether or not such a reserve is required by state statute. If this is a prudent requirement recognized by one state, which, by statute, requires the accumulation of a reserve, the identical circumstances in this respect prevail and warrant its application to cooperatives in other. states, the statutes of which may not require this accumulation. However, it seems proper that definitive maximum limits on the accumulation of these reserves should be spelled out in the Regulations, as well as a limit on the percentage of annual net savings or margins which could be appropriated in the accumulation of these reserves. This purpose could be accomplished by limiting the annual appropriations to this reserve to an amount not in excess of 20 per cent of the annual net savings or margins realized, provided that the reserve to be accumulated shall not exceed the higher of:

I. $5^{\circ}$ per cent of the combined capital, funded debt, and accumulated capital reserves, as defined; or

2. The average annual operating expenses during the preceding three years. (If the cooperative has been in existence less than three years, the period of its existence shall be used in determining the average annual operating expense.)

With respect to this second class of reserves-namely, contingent reservessince the amount which can be accumulated is definitely limited, and further, since the reserve is created for the purpose of absorbing shocks and losses, so that patrons' equities therein may be in a state of constant flux from year to year, the patrons'

"U. S. Treas. Reg. III, 529.23 (1943). 
individual equities need not be definitely allocated. The cooperative, however, must be required to maintain adequate records of patronage so that in the event of dissolution, liquidation or any other authorized distribution from this reserve, the distribution will be made to patrons on the basis of past patronage; with the further provision that the patronage basis may be limited to the patronage of the five years immediately preceding the liquidation or dissolution. Under this provision, since patrons' equities in this class of reserve would not be allocated, they would be taxable to the patron only upon distribution.

3. Capital reserves. The third category of reserves would be classed as "capital reserves" and would embrace any amounts retained by the cooperative association for any purpose other than those covered by the preceding two categories. The amounts retained in capital reserves should be evidenced by the issue to each patron of some evidence of equity in one or more of the following forms:

I. Capital stock, subject to the limitations as to dividends and ownership prescribed by the statute.

2. Bonds, certificates of indebtedness, or notes.

3. Certificates of ownership or equity, or other form of evidence of equity.

The effect of the foregoing provisions would be that the entire net margins or savings of the association not needed for (a) valuation reserves, (b) contingent reserves, or (c) to pay dividends on capital shares outstanding, would be distributed to the patrons annually either in cash or in some form of evidence of equity. The Regulations should therefore be amended to define the rules with respect to the taxation to the patron of amounts distributed to him in forms other than cash. This would require an amendment of Section 29.42-2 of Regulations III, which defines the constructive receipt of income, to include definitely such distributions as income constructively received by the patron-taxpayer.

It is suggested that any evidence of equity issued to patrons as a patronage refund, which does not have a definite maturity date within ten years from the date of issue, should constitute taxable income to the patron in the year of issue to him. The amount to be included in the patrons' returns should be the face amount of proceeds or patronage margins represented by the distribution, without regard to the market or actual value of the evidence of interest distributed. Where the distribution has been in the form of revolving-fund certificates or other evidences of equity which have a maturity date within ten years after the date of issue, or which are subject to retirement on or after the maturity date by the application to such retirement of all net margins or savings realized by the association after the maturity date, then these amounts should be taxable to the patron when the cash payment, or its equivalent, is received by him. If at the time of maturity of these evidences of equity they are paid, not in cash, but by other evidences of equity, or debt of the issuer, or by renewal or extension of the original form of evidence of equity, the re-issue, renewal, or issue of other evidence of equity should be construed as pay- 
ment and should become taxable income to the patron on the maturity date of the original evidence of equity.

There is a valid reason for making certain distinctions in the time for taxing the value of these evidences of equity to patrons. Many farmer cooperatives have long followed the custom of paying patronage refunds in revolving-fund certificates, which are redeemed in cash as they become due. In many sections of the country, farmer owners of these certificates have followed the practice of taking the proceeds of these certificates into their taxable incomes in the year in which payment is received. If the tax is to be assessed only with respect to the issue of the evidence of equity, then it would not apply to those already issued. On the other hand, if provision should be made to tax to the patron the proceeds in redemption of those issues which are already outstanding, as they are received by the patron, and at the same time to tax him on the face value of equities being currently issued, there would be an unjust pyramiding of tax to the patron of two, or more, years' equities in one taxable period. Furthermore if the "constructive receipt" rule, which would make the face value of evidences of equity taxable to patrons when issued, were to be applied without an exception for those issued with deferred maturities, the Treasury might be barred from collecting the tax on proceeds in retirement of evidences of equity issued in earlier years with respect to which the statutory period for collection had expired.

'To carry out these suggestions concerning reserves and the taxation of patrons' equities therein the applicable provisions of the Treasury Regulations might be amended as follows.

\section{Regulations III:}

Sec. 29.Ior(12) I-That part applicable to reserves to be amended to read:

The accumulation and maintenance of a reserve required by State statute, or the accumulation and maintenance of a reasonable reserve or surplus for any necessary purpose, such as to provide for the erection of buildings and facilities required in business or for the purchase and installment of machinery and equipment, or to retire indebtedness incurred for such purposes, will not destroy the exemption; provided, however, that the accumulation of such reserves shall be in accordance with and subject to the following rules:

(A) In the accrual of additions to reserves for depreciation, depletion, bad debts and other reserves affecting the valuation of assets, the cooperative association shall be governed by the same rules and limitations which apply to any non-exempt taxpayer with respect thereto.

(B) A cooperative association may accumulate a reserve for contingencies by the appropriation of not more than 20 per cent of its net margins or savings for any year, provided that such reserve for contingencies shall not exceed the higher of:

(I) $5^{\circ}$ per cent of the combined capital, funded debt, and accumulated capital reserves as defined herein.

(2) The average annual operating expenses incurred during the preceding three years. (If the corporation has been in existence less than three years, the 
period of its existence shall be used in determining the average annual operating expense.)

(C) Any amounts retained by the association as additions to reserves for any other purposes than valuation of assets, or provision for contingencies, as provided in (A) and (B) above, shall be considered as contributions to the capital reserves of the association, and within twelve months from the close of the year with respect to which such amounts are retained, there shall be issued to each patron of the association a certificate or other definite evidence of his respective equity in the amounts so retained by the association as capital. Evidences of equity distributed pursuant to this Section shall be taxable to the recipients as provided in these regulations, Section $29.42-2$, as amended.

Regulations III:

Section 29.42-2-Add after the final word ("receipt") of the present regulation, the following:

But with respect to distributions by cooperative associations of patronage refunds in the form of evidences of equity as provided in Sec. 29.Ior(I2) I of these Regulations, the following provisions shall govern:

(A) Where such evidence of equity does not have a definite maturity date within ten years from the date of issue, the amount for which such evidence of equity was issued shall constitute taxable income to the recipient in the year of issue, as constructively received by him and reinvested in the securities of the issuing association.

(B) Where such evidence of equity has a maturity date within ten years, or less, after the date of issue, or is subject to retirement on or after the maturity date by the application to such retirement of all net margins or savings realized by the issuing association after such maturity date, then such amounts shall be taxable to the respective patron when the cash payment, or its equivalent, is received by him; provided, that if at the time of maturity of such evidences of equity, they be paid, not in cash or property, but by other evidence of equity or debt of the issuer or by renewal or extension of the original form of evidence of equity, then such reissue, renewal, or issue of other evidence of equity shall constitute payment, and become taxable income to the patron on the maturity date of the original evidence of equity.

4. Information reports. With respect to reports of information at the source, it has been generally considered that payments of patrons' refunds do not constitute the payment of fixed and determinable income, as covered by the present provisions of Section 29.147 of Regulations III. Furthermore, in the payment of patronage refunds by many cooperative associations, there is involved a multitude of small items, the reporting of which would be burdensome to both the cooperative association and the Treasury Department. It is therefore suggested that all patronage distributions made to patrons by cooperative associations, either in cash or in forms of evidence of equity which are presently taxable to the patron, should be reported by the cooperative, subject to the limitation that any payment of less than $\$ 100.00$ to any patron in any year need not be reported. This could be accomplished by amending Section 29.147 of the Regulations to provide that the cooperative associa- 
tion shall report this information, but that these reports shall be made in the form of a list to be presented annually, within nine months from the close of the fiscal year, to the Internal Revenue Agent in Charge in the district in which the principal office of the cooperative association is located. Where a cooperative association operates in more than one Internal Revenue District, the information lists with respect to residents in the respective districts should be filed with the Agent in Charge for each district. The following amendment of the Regulations is suggested:

\section{Regulations III:}

Section 29.147-I-Add after the last word of the Section ("disposition") the following:

Except that with respect to amounts distributed by cooperative associations as patronage refunds, the fact of payment shall be determined as provided in Section 29.42-2 of the regulations, pertaining to the constructive receipt of income.

Returns of information with respect to payments of patronage refunds shall be made as to all amounts of $\$ 100.00$ or more paid or credited in any year, but such returns shall not be made on Forms rogg and rog6, but shall be in the form of a list giving the names and addresses of the distributees and amounts of all such patronage distributions; such lists to be filed within nine months from the close of the fiscal year of such association with the Internal Revenue Agent in Charge in the district in which the association operates, or if the association operates in more than one Internal Revenue District, such information lists with respect to residents in the respective districts shall be filed with the Agents in Charge for such districts.

5. Statute of Limitations-Applicability to Exempt Agricultural Cooperatives. The Revenue Act of 1943 provided that organizations exempt from corporation income taxes under the provisions of Section ror of the Internal Revenue Code should annually file a report of information. ${ }^{4}$ The report which the Commissioner has adopted for this purpose is a revision of Form $990.0^{\circ}$ At the time this revision of the Code was adopted by Congress in I943, there was considerable discussion in committee hearings as to the applicability of the statute of limitations to exempt organizations, and there was evidence that it was the intent of Congress that the filing of the annual report thus called for should be acceptable as a return to start the running of the statute as provided in Sections 275 and 276 of the Internal Revenue Code. ${ }^{B}$ Accordingly, the Commissioner of Internal Revenue, on June 8, I944, issued a ruling to the effect that the timely filing of the prescribed form of report, completely filled in, would be accepted as a return as called for in Sections 275 and 276 of the Code, and would start the running of the statute of limitations. It is recommended that this ruling be made the subject of a definite Regulation, and therefore, the adoption of the following amendment to Section 275 of the Regulations is suggested:

\footnotetext{
Regulations III: To become Sections 29.275-I(I2) and 29.275-2(6).

For the purposes of Sections 275 and 276 of the Internal Revenue Code, the -INT. Rev. Code \$54(f).

$\checkmark$ U. S. Treas. Reg. IIr, \$29.101-2(c) (1943).

${ }^{\circ} 54$ StAT. 1007, 53 STAT. 87,26 U.S.C. $\$ \$ 273,276$ (1940).
} 
filing of the annual return required by Section 54 (f) of the Internal Revenue Code, as amended by the Section II 7 , Revenue Act of 1943 , by corporations exempt from Corporation Income and Profits Taxes under Section ror of the Internal Revenue Code, shall constitute the filing of a return as required in this section, to start the period of limitations.

The adoption and application of the additions or changes in the Treasury Regutions herein suggested should operate to give ample assurance that margins of exempt cooperatives will not escape ultimate taxation, but will, in fact, be taxed at a definite time and at a stated value to the patron to whom they belong. This would effectively correct any valid grounds for criticism which may now exist. 